\title{
Dinamika Komunikasi dalam Pandemi COVID-19
}

\author{
Eka Nada Shofa Alkhajar \\ Sri Herwindya Baskara Wijaya \\ Editor
} ${ }^{1}$ Alkhajar, E. N. S., \& Wijaya, S. H. B. (Eds.). (2020). Dinamika Komunikasi dalam Pandemi
COVID-19. Yogyakarta: KBM Indonesia. 


\section{DINAMIKA KOMUNIKASI \\ DALAM PANDEMI COVID-19}

Eka Nada Shofa Alkhajar, Sri Herwindya Baskara Wijaya, Dewanto Putra Fajar, Dhyah Ayu Retno Widyastuti, Anastasia Lilin Yuliantina, Andi Nugroho, Mulyanto Utomo, Yuliana Rakhmawati, Catur Nugroho, Nikmah Suryandari, Zon Vanel, Monika Sri Yuliarti, Firdastin Ruthnia Yudiningrum, Yunizar Riswanda Ardi, Likha Sari Anggreni 
DINAMIKA KOMUNIKASI DALAM PANDEMI COVID-19

Copyright $@ 2020$

All Rights Reserved

\section{Penulis:}

Eka Nada Shofa Alkhajar, Sri Herwindya Baskara Wijaya, Dewanto Putra Fajar, Dhyah Ayu Retno Widyastuti, Anastasia Lilin Yuliantina, Andi Nugroho,

Mulyanto Utomo, Yuliana Rakhmawati, Catur Nugroho, Nikmah Suryandari, Zon

Vanel, Monika Sri Yuliarti, Firdastin Ruthnia Yudiningrum, Yunizar Riswanda

Ardi, Likha Sari Anggreni

\section{Editor:}

Eka Nada Shofa Alkhajar

Sri Herwindya Baskara Wijaya

\section{Perancang Sampul:}

Adji Kreatif

Tata Letak:

Ainur Rochmah

\section{Ukuran:}

$14 \mathrm{x} 21 \mathrm{~cm} ; \mathrm{x}+210 \mathrm{hlm}$

ISBN:

978-623-6509-02-9

\section{Cetakan Pertama:}

Juni 2020

\section{Penerbit:}

KBM Indonesia, Yogyakarta 


\title{
KATA PENGANTAR EDITOR:
}

\author{
Buku, Kampus Hijau dan Pandemi COVID-19
}

Ide penulisan buku ini berawal dari diskusi hangat yang dilakukan secara daring oleh beberapa alumni Ilmu Komunikasi Universitas Sebelas Maret (UNS), Surakarta. Diskusi tersebut menelurkan gagasan untuk ikut merefleksikan pandemi Coronavirus Disease 2019 (COVID-19) ke dalam sebuah buku.

COVID-19 adalah ancaman nyata seluruh umat manusia dewasa ini. Penyakit yang telah menginfeksi jutaan manusia seantero dunia ini telah mengisi catatan lembaran sejarah peradaban manusia. Jika menilik ke belakang, awalnya penyakit ini merebak di Kota Wuhan, Provinsi Hubei, Tiongkok. Namun, akibat meluasnya persebaran penyakit tersebut, Organisasi Kesehatan Dunia (World Health Organization, WHO) pada 30 Januari 2020, mendeklarasikan kondisi darurat kesehatan publik internasional (Public Health Emergency of International Concern, PHEIC).

Akan tetapi, seiring berjalan cakupan wilayah infeksi COVID-19 ternyata semakin bertambah luas meliputi ratusan negara sehingga pada 11 Maret 2020, akhirnya WHO mengumumkan COVID-19 sebagai sebuah pandemi global (global pandemic). Ratusan negara di dunia kini tengah berjibaku melawan pandemi tersebut sekaligus beradaptasi dan berdamai sebaik mungkin dengannya. Penyakit ini jelas tidak main-main karena telah menginfeksi jutaan manusia di seantero dunia.

COVID-19 tentu tidak hadir tanpa alasan. Dan apapun alasannya, kita semua harus bisa mengambil hikmah dan pelajaran dari pandemi ini. Benar, semua manusia tanpa kecuali harus belajar dari COVID-19. Dalam kerangka tujuan itulah buku ini hadir. Buku ini ditulis oleh alumni kampus hijau (green campus) lintas generasi dengan aneka topik yang berkaitan erat dengan komunikasi dan COVID-19.

Buku ini tersusun atas kumpulan bab-bab buku (book chapters) dari para penulisnya. Kami selaku editor buku menyampaikan apresiasi dan terima kasih sebesar-besarnya kepada para penulis yang telah bersedia meluangkan waktu dan pikiran untuk menuliskan gagasannya. Buku ini adalah sebentuk refleksi dari para penulis mengenai pandemi COVID-19 yang saat ini tengah kita hadapi bersamasama. Untuk itu, selamat membaca dan semoga bermanfaat.

Kota Bengawan, Mei 2020

Eka Nada Shofa Alkhajar Sri Herwindya Baskara Wijaya 


\section{DAFTAR ISI}

KATA PENGANTAR EDITOR …......................................................... vi

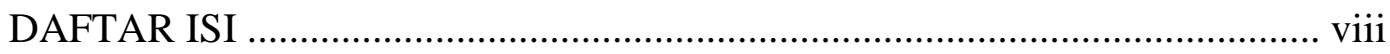

BAGIAN I

MEDIA, JURNALISME DAN PANDEMI COVID-19 ................................... 1

BAB 1 The Second Hand-Reality: Dinamika Komunikasi Jelang Pandemi dan Respons Media (Eka Nada Shofa Alkhajar) .................................... 2

BAB 2 Dilema Jurnalis di Pusaran Pandemi COVID-19: Tidak Ada Berita Seharga Nyawa! (Sri Herwindya Baskara Wijaya) ................................ 29

BAB 3 Pengaruh Negatif Pemberitaan COVID-19 pada Kondisi Fisiologis Audien (Dewanto Putra Fajar) ......................................................................... 44

BAB 4 Paradoks Jurnalis dan Efek Media dalam Pemberitaan Seputar COVID-19

(Firdastin Ruthnia Yudiningrum \& Yunizar Riswanda Ardi) ................. 57

\section{BAGIAN II}

INFORMASI DAN KOMUNIKASI DI ERA COVID-19

BAB 5 Pemrosesan Informasi dan Pengurangan Ketidakpastian dalam Pandemi

COVID-19 (Dhyah Ayu Retno Widyastuti) 66

BAB 6 Information Disorder: Silang Sengkarut Informasi dalam Pandemi COVID-19 (Catur Nugroho)

BAB 7 Difabel dan Kendala Komunikasi di Tengah Pandemi COVID-19 (Mulyanto Utomo) 90

BAB 8 Entropi dan Mitigasi Informasi Pandemi COVID-19 dalam Ruang Domestik (Yuliana Rakhmawati) 98

BAB 9 External Communication Strategy of YPLAG Peace Project's "Unite Against COVID-19" (Zon Vanel) 107

\section{BAGIAN III}

DUNIA SIBER, VIRTUALISASI DAN REFLEKSI TERHADAP COVID-19

BAB 10 COVID-19 dan Ancaman Siber di Sekitar Kita (Andi Nugroho) ........ 120

BAB 11 Pandemi COVID-19, Deglobalisasi dan Virtualisasi Komunikasi (Nikmah Suryandari)

BAB 12 Antara Thanos, COVID-19 dan Masa Depan Manusia 


\section{BAGIAN IV}

KOMUNIKASI TERMEDIASI DAN PEMBELAJARAN DARING DI ERA COVID-19

BAB 13 Perspektif Hyperpersonal dalam Komunikasi Bermedia (Computer dan Mobile): Mungkinkah Terjadi dalam Masa Pandemi COVID-19? (Monika Sri Yuliarti) 168

BAB 14 Komunikasi Termediasi dan Momentum Revitalisasi Pembelajaran Daring (Eka Nada Shofa Alkhajar)

BAB 15 Komunikasi Orang Tua, Guru dan Anak: Penggunaan Media Daring dalam Pembelajaran Selama Pandemi COVID-19

(Likha Sari Anggreni) 